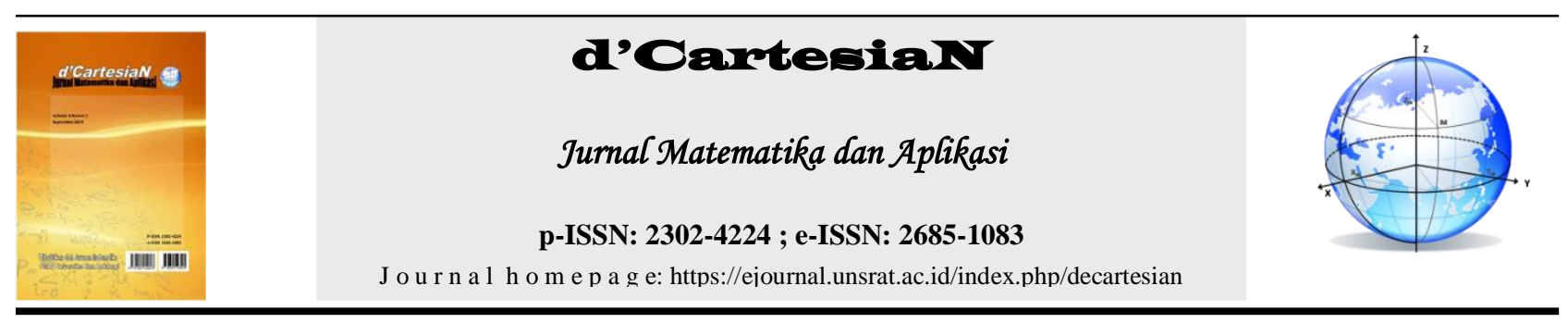

\title{
Analisis Faktor - Faktor yang Mempengaruhi Produksi Getah Pinus di Kabupaten Poso
}

\author{
Jesi A. lateka1, Tohap Manurung ${ }^{1}$, Jantje D. Prang ${ }^{{ }^{*}}$ \\ ${ }^{1} J u r u s a n$ Matematika-Fakultas Matematika dan Ilmu Pengetahuan Alam-Universitas Sam Ratulangi Manado, Indonesia
}

${ }^{*}$ Corressponding author : jantjedprang@yahoo.com

\begin{abstract}
A B S T R A K
Kabupaten Poso merupakan titik berat produktivitas getah pinus yang ada di Sulawesi Tengah, sehingga sangat penting untuk mengetahui faktor-faktor yang mempengaruhi hasil produksi getah pinus di Kabupaten Poso. Mengacu pada beberapa penelitian sebelumnya, akumulasi berbagai faktor dapat menyebabkan suatu persoalan atau suatu kejadian dipicu oleh berbagai peristiwa sebelumnya, untuk menduganya digunakan persamaan regresi linier berganda yang dapat merangkum berbagai faktor tersebut. Data yang digunakan dalam penelitian ini adalah data luas lahan setiap kelompok $\left(X_{1}\right)$, jumlah tenaga kerja kelompok $\left(X_{2}\right)$ dan jumlah jam kerja kelompok $\left(X_{3}\right)$. Berdasarkan hasil analisis regresi linier berganda terjadi gejala multikolinearitas antara variabel jumlah tenaga kerja dan jumlah jam kerja, oleh karena itu untuk mengatasinya maka diambil salah satu variabel yaitu jumlah tenaga kerja. Hasil analisis didapat bahwa variabel luas lahan dan jumlah tenaga kerja secara simultan mempengaruhi hasil produksi getah pinus dengan koefisien determinasi sebesar 93\%.
\end{abstract}

\section{INFO ARTIKEL}

Diterima

Diterima setelah revisi

Tersedia online

\section{Kata Kunci:}

Analisis Regresi Linier Berganda

Hutan Pinus di Kabupaten Poso

\begin{abstract}
A B S T R A C T
Poso Regency is a center of productivity for pine resin in Central Sulawesi, so it is very important to know the factors that influence the production of pine sap in Poso District. Referring to several previous studies, the accumulation of various factors can cause a problem or an event triggered by various previous events, to predict the use of multiple linear regression equations that can summarize these various factors. The data used in this study are data on the land area of each group $\left(X_{1}\right)$, the number of group workers $\left(X_{2}\right)$ and the number of hours of group work $\left(X_{3}\right)$. Based on the results of multiple linear regression analysis there is a symptom of multicollinearity between the variables of the number of workers and the number of hours worked, therefore to overcome this one variable is taken, namely the number of workers. The results of the analysis show that the variable area of land and the number of labor simultaneously affect the production of pine sap with a determination coefficient of $93 \%$.
\end{abstract}

\section{PENDAHULUAN}

Hutan adalah karunia alam yang memiliki potensi dan fungsi untuk menjaga keseimbangan lingkungan. Potensi dan fungsi tersebut mengandung manfaat bagi populasi manusia bila dikelola dengan benar dan bijaksana. Salah satu hutan yang banyak memberikan potensi dan fungsi bagi populasi manusia adalah hutan pinus.

Tumbuhan pinus banyak memberikan manfaat bagi manusia terutama bagi masyarakat Indonesia. Pinus Merkussi atau Tusam (Pinus merkusii Jungh. Et deVries) merupakan satu-satunya jenis pinus yang tumbuh asli di Indonesia. Pohon pinus memiliki banyak kegunaan yaitu untuk penghasil kayu, produksi getah dan konservasi lahan. Getah pinus merupakan salah satu komoditi hasil hutan bukan kayu yang cukup potensial. Indonesia merupakan negara urutan ke tiga dalam produksi getah pinus setelah Cina dan Brasil.

Ada beberapa daerah di Indonesia yang menjadikan hutan pinus sebagai sumber mata pencaharian bagi masyarakatnya dalam memproduksi getah, salah satunya Kabupaten Poso yang merupakan titik berat produktivitas getah pinus yang ada di Sulawesi Tengah. Pada sebagian wilayah hutan dibagi beberapa lahan penyadapan yang dikerjakan oleh kelompok petani. Cara penyandapan getah yang dilakukan oleh petani getah pinus di kabupaten Poso yaitu sistem koakan atau petani di sana menyebutnya dengan mowingku. Koakan dibuat sejajar panjang batang dengan kedalaman $2 \mathrm{~cm}$ dan lebar $10 \mathrm{~cm}$ dengan menggunakan alat sadap konvensional yang disebut kedukul/petel atau alat semi mekanis yaitu mesin mujitech [1].

Getah yang dihasilkan oleh pohon pinus ada dua jenis yaitu gondorukem dan terpentin. Gondorukem 
dipergunakan dalam industri batik, plastik, sabun, tinta cetak, bahan plitur sedangakan terpentin digunakan sebagai bahan pelarut cat. Dengan semakin meningkatnya kebutuhan manusia, maka prospek getah gondorukem dan terpentin untuk industri sangat cerah, sehingga peranan hutan pinus sebagai penyuplai industri tersebut harus tetap lestari. Oleh karena itu, perlu diadakan upaya peningkatan produksi getah pinus.

Produksi getah pinus dipengaruhi oleh faktor internal dan eksternal. Faktor internal berasal dari sifat dasar pohon dan faktor eksternal berasal dari lingkungan [2].

Penelitian ini dilakukan untuk menganalisis pengaruh faktor-faktor yang mempengaruhi hasil produksi getah pinus dengan menggunakan model regresi linier berganda.

\section{Tanaman Pinus (Tusam)}

Pohon pinus pertama kali ditemukan di daerah Sipirok, Tapanuli Selatan Sumatera Utara oleh seorang ahli botani Jerman yaitu Dr. F. R. Junghuhn pada tahun 1841. Pinus pada umumnya batang berkayu, bulat, keras, bercabang horizontal, kulit retak-retak seperti saluran dan berwarna cokelat, daunnya majemuk dan berbentuk jarum, memiliki buah dengan perisai ujung berbentuk jajar genjang, akhirnya merenggang, tinggi kisaran 20-40 $\mathrm{m}$ dan diameter 30$60 \mathrm{~cm}$ [3]. Tumbuhan ini tergolong jenis cepat tumbuh dan tidak membutuhkan persyaratan yang khusus.

Pinus merkussi atau sering disebut dengan tusam salah satu jenis pohon industri yang mempunyai produk tinggi dan merupakan prioritas jenis tanaman untuk reboisasi. Pinus termasuk dalam jenis pohon serba guna yang terus menerus dikembangkan dan diperluas masa penanamanya pada masa mendatang untuk penghasil kayu produksi, getah getah dan konservasi lahan [4].

\section{Penyadapan Getah Pinus}

Getah pinus adalah semacam oleoresin yaitu campuran senyawa komplek resin dan terpentin berupa cairan kental dan lengket, bening atau buram. Getah atau resin terbentuk sebagai akibat proses metabolisme sekunder dalam pohon. Getah berfungsi untuk melindugi sel-sel yang sedang tumbuh, memacu aktivitas pertumbuhan untuk penutupan luka mekanis jika terjadi serangan hama serta penyakit [5].

Getah pinus didapatkan jika batang pohon pinus dilukai (disadap). Prinsip keluarnya getah dari luka adalah saluran getah pada semua sisi dikelilingi oleh jaringan parenkim, dan di antara saluran getah dan selsel parenkim terdapat keseimbangan osmotik. Jika dibuat luka pada batang pinus maka saluran getahnya akan terbuka mengakibatkan tekanan dinding terbuka sehingga getah keluar.

Ada beberapa sistem atau teknik penyadapan yang sering dilakukan untuk memanen getah pinus, yaitu :

1. Sistem koakan

Teknik ini dilakukan dengan cara mengerok kulit batang lebih dulu, kemudian kayunya dilukai sedalam 1-2 cm, sedang lebarnya $10 \mathrm{~cm}$. Pelukaan dengan cara ini membentuk huruf $U$ terbalik dengan jarak dari permukaan tanah sekitar 15-20 cm.

2. Sistem Kopral
Teknik ini hampir sama dengan teknik koakan, tetapi berbentuk $\mathrm{V}$ dapat juga dimodifikasi menjadi $\mathrm{V}$ ganda atau seri ke arah atas (rill) yang bentuknya seperti sirip ikan, dilukai dengan lebar $15 \mathrm{~cm}$, kedalaman $1 \mathrm{~cm}$.

3. Sistem Bor

Tenik ini menggunakan bor listrik yang dilengkapi dengan jenset. Pembuatan luka sadap dimulai dari bagian pangkal batang ke arah atas, luka sadap berbentuk lubang diameter 2,2 cm dengan kedalaman 4-8 cm.

\section{Faktor-Faktor Yang Mempengaruhi Produksi Getah Pinus}

Faktor internal pohon yaitu jenis pohon, persen kayu gubal, kesehatan pohon, sistem perakaran, persen tajuk. Faktor eksternal terdiri dari jarak tanam, iklim dan tempat tumbuh, bonita, umur pohon dan luas tempat tumbuh. Adapun faktor-faktor yang terjadi akibat perlakuan sadapan yang dilakukan manusia, yaitu bentuk sadapan, arah sadapan, arah pembaharuan, waktu penyimpanan, upaya stimulasi, jumlah penyadap, waktu kerja penyadap.

\section{Analisis Regresi Berganda}

Akumulasi berbagai faktor dapat menyebabkan suatu persoalan dalam kehidupan di sekitar kita tiap harinya. Sebuah kejadian dipicu oleh berbagai peristiwa sebelumnya, sehingga untuk menduganya diperlukan sebuah persamaan matematik yang bisa merangkum berbagai faktor tersebut. Persamaan matematik yang dibuat untuk memecahkan persoalan tersebut adalah persamaan regresi linier berganda [6].

Analisis regresi linier berganda adalah di mana variabel terikatnya $(\mathrm{Y})$ dihubungkan atau dijelaskan lebih dari satu variabel, mungkin dua, tiga, dan seterusnya variabel bebas $\left(\mathrm{X}_{1}, \mathrm{X}_{2}, \mathrm{X}_{3}, \ldots, \mathrm{X}_{\mathrm{n}}\right)$ namun masih menujukkan diagram hubungan yang linier. Penambahan variabel bebas ini diharapkan dapat lebih menjelaskan karakteristik hubungan yang ada walaupun masih saja ada variabel yang terabaikan [7].

Menurut peneliti sebelumnya [8] analisis regresi linier berganda memberikan kemudahan bagi pengguna untuk memasukkan lebih dari satu variabel bebas, sehingga model regresi berganda untuk populasi dapat ditunjukan sebagai berikut :

$$
Y=\beta_{0}+\beta_{1} X_{1}+\beta_{2} X_{2}+\cdots+\beta_{k} X_{k}+e
$$

Dimana :

$Y=$ variabel dependent

$\beta_{i}=$ parameter koefisien regresi, $\mathrm{i}=1,2, \ldots \mathrm{k}$

$X_{i}=$ variabel independen, $\mathrm{i}=1,2, . . \mathrm{k}$

$e=$ standar error

Model regresi linier berganda untuk populasi di atas dapat ditaksir berdasarkan sebuah sampel acak yang berukuran $k$ dengan model regresi linier berganda untuk sampel, yaitu :

$$
\hat{Y}=b_{0}+b_{1} X_{1}+b_{2} X_{2}+\cdots+b_{k} X_{k}
$$

\section{Uji Asumsi Klasik}

\section{Uji Normalitas}

Uji normalitas bertujuan apakah dalam model regresi variabel dependen dan variabel independen mempunyai konstribusi atau tidak. Model regresi yang baik adalah data distribusi normal atau mendekati normal [9]. 


\section{Uji Heterokedastisitas}

Uji heteroskedastisitas bertujuan menguji apakah dalam model regresi terjadi ketidaksamaan varian dan residual satu pengamatan ke pengamatan yang lain. Jika varian dan residual satu pengamatan ke pengamatan lain tetap, maka disebut homoskedastisitas dan jika berbeda disebut heterokedastisitas [9].

\section{Uji Multikolinearitas}

Uji multikolinearitas bertujuan untuk menguji apakah suatu model regresi terdapat korelasi antar variabel bebas (independen). Model regresi yang baik seharusnya tidak terjadi korelasi antar variabel independen. Pengujian multikolinearitas dilihat dari besaran VIF (Variance Inflation Faktor) dan tolerance. Tolerance mengukur variabel independen yang terpilih yang tidak dijelaskan oleh variabel independen lainnya. Jadi nilai tolerance yang rendah sama dengan nilai VIF yang tinggi (karena VIF $=1 /$ tolerance ). Nilai cutoff yang umum dipakai untuk menunjukan adanya multikolinearitas adalah nilai tolerance $\geq 0,01$ atau sama dengan nilai VIF $\leq 10$ [9].

\section{Uji F (Simultan)}

Uji statististik $\mathrm{F}$ pada dasarnya menunjukkan apakah semua variabel indepennden atau variabel bebas yang dimasukan dalam model mempunyai pengaruh secara bersama-sama terhadap variabel dependen atau variabel terikat [9].

Untuk menguji hipotesis ini digunakan statistik $\mathrm{F}$ dengan kriteria pengambilan keputusan sebagai berikut:

a. Jika nilai signifikansi $<0,05$ maka $H_{0}$ ditolak pada derajat kepercayaan 5\% dengan kata lain kita menerima hipotesis alternatif, yang menyatakan bahwa semua variabel independen secara serentak dan signifikan mempengaruhi variabel dependen.

b. Membandingkan nilai $\mathrm{F}$ hasil perhitungan dengan F menurut tabel. Bila nilai $F_{\text {hitung }}$ lebih besar daripada nilai $F_{\text {tabel }}$, maka $H_{0}$ ditolak dan $H_{1}$ diterima.

Untuk mencari nilai $F_{\text {tabel }}$ digunakan persamaan sebagai berikut:

$$
F_{\text {tabel }}=F(k ; n-k)
$$

Dimana :

$k=$ jumlah variabel bebas (independen)

$n=$ jumlah data

\section{Uji t (Parsial)}

Uji $t$ digunakan untuk menguji seberapa jauh pengaruh variabel independen yang digunakan dalam penelitian ini secara individual dalam menerangkan variabel dependen secara parsial [9].

Dasar pengambilan keputusan digunakan dalam uji t adalah sebagai berikut:

a. Jika nilai probabilitas signifikansi > 0,05 maka hipotesis ditolak. Hipotesis ditolak mempunyai arti bahwa variabel independen tidak berpengaruh signifikan terhadap variabel dependen.

b. Jika nilai probabilitas signifikansi $<0,05$, maka hipotesis diterima. Hipotesis tidak dapat ditolak mempunyai arti bahwa variabel independen berpengaruh signifikan terhadap variabel dependen.

Untuk mencari nilai $t_{\text {tabel }}$ digunakan persamaan sebagai berikut:

$$
t_{\text {tabel }}=t(\alpha / 2 ; n-k-1)
$$

Dimana : $k=$ jumlah variabel bebas (independen)

$n=$ jumlah data

$\alpha=$ tingkat kepercayaan

\section{Koefisien Determinasi $\left(R^{2}\right)$}

Koefisien determinasi $\left(R^{2}\right)$ merupakan alat untuk mengukur seberapa jauh kemampuan model dalam menerangkan variasi variabel dependen. Nilai koefisien determinasi adalah antara o sampai dengan 1. Nilai koefisien determinasi yang kecil berarti kemampuan variabel-variabel independen dalam menjelaskan variasi variabel dependen sangat terbatas. Dan sebaliknya jika nilai yang mendekati 1 berarti variabelvariabel independen memberikan hampir semua informasi yang dibutuhkan untuk memprediksi variabel-variabel dependen [9].

\section{METODE PENELITIAN}

\subsection{Objek Penelitian}

Penelitian ini dilakukan di Kabupaten Poso Provinsi Sulawesi Tengah dengan objek penelitian 27 kelompok tani hutan pengelola getah pinus. Kelompok ini dibentuk oleh masyarakat sendiri atas persetujuan pemerintah dan tersebar dibeberapa desa di Kabupaten Poso, yang disajikan dalam tabel 1 berikut :

\begin{tabular}{|c|c|c|}
\hline No & Nama KTH & Kecamatan \\
\hline 1 & Pada Mpodile & \\
\hline 2 & Pondo & \\
\hline 3 & Inaya & \\
\hline 4 & Marantole & \\
\hline 5 & Baulabuta & \\
\hline 6 & Buyulabu & \\
\hline 7 & Tembe & \\
\hline 8 & Patoto & \\
\hline 9 & Pu'untana & \\
\hline 10 & Kasolo'u & Pamona Timur \\
\hline 11 & Pemeto & \\
\hline 12 & Kasa Moto & \\
\hline 13 & Pu'untana & \\
\hline 14 & Pengawa & \\
\hline 15 & Mancebi & \\
\hline 16 & Pebata & \\
\hline 17 & Pada Meura & \\
\hline 18 & Talinti & \\
\hline 19 & Roka & \\
\hline 20 & Buyu gusi & Pamona utara \\
\hline 21 & Petoyo & \\
\hline 22 & Korongiri & \\
\hline 23 & Sintuwu raya & Pamona \\
\hline 24 & Palapa lestari & Puselemba \\
\hline 25 & Hambu & \\
\hline 26 & Poharea & Lore Peore \\
\hline
\end{tabular}

Tabel 1. Daftar Nama Kelompok Tani Hutan 


\begin{tabular}{lll}
\hline 27 & Welanti & Lore Timur \\
\hline
\end{tabular}

\subsection{Waktu dan Tempat Penelitian}

Penelitian ini dilakukan pada bulan Januari 2018 Mei 2019. Untuk pengambilan data dilakukan di Kabupaten Poso Sulawesi tengah dan penyusunan serta analisis data dilakukan di Fakultas MIPA UNSRAT Laboratorium Statistika Dasar.

\subsection{Populasi dan Sampel Penelitian}

Populasi dalam penelitian ini adalah seluruh kelompok tani hutan (KTH) yang ada di Kabupaten Poso yang terdiri dari 27 kelompok dan dalam penelitian ini sampel yang digunakan diambil dari seluruh populasi.

\subsection{Metode Pengumpulan Data}

Data yang digunakan dalam penelitian ini adalah data primer mengenai faktor-faktor yang mempengaruhi produksi getah pinus dengan wawancara langsung kepada beberapa petani yang mewakili setiap kelompok tani hutan serta penelitian langsung di lokasi penyadapan getah pinus dan data sekunder mengenai hasil produksi getah pinus yang di dapatkan dari kantor dinas kehutanan Kesatuan Pengelolaan Hutan (KPH) Sintuwu Maroso Kabupaten Poso Sulawesi Tengah.

\subsection{Variabel Penelitian}

Variabel yang digunakan dalam penelitian ini menyangkut luas lahan, jumlah tenaga kerja dan jumlah jam kerja yang dijelaskan sebagai berikut :

1) Luas lahan $\left(X_{1}\right)$, adalah luas area pengolaan getah yang dimiliki oleh setiap kelompok tani hutan, dengan menggunakan satuan hektare ( $\mathrm{Ha}$ ).

2) Jumlah tenaga $\operatorname{kerja}\left(X_{2}\right)$, adalah jumlah seluruh tenaga kerja manusia pada setiap kelompok tani hutan, dengan menggunakan satuan perorang.

3) Jumlah jam kerja $\left(X_{3}\right)$, adalah jumlah waktu bekerja setiap kelompok tani hutan, dengan menggunakan satuan jam.

4) Jumlah hasil produksi (Y), adalah jumlah hasil produksi getah pinus saat panen setiap kelompok tani hutan, dengan menggunakan satuan kilogram (kg).

\subsection{Pengujian Hipotesis}

$H_{0}$ : Diduga tidak terdapat pengaruh variabel $X$ terhadap variabel $Y$.

$H_{1}$ : Diduga terdapat pengaruh variabel $X$ terhadap variabel $Y$.

Dengan menggunakan tingkat kepercayaan 95\% atau $\alpha$ $=0,05$.

\section{HASIL DAN PEMBAHASAN}

\subsection{Faktor-Faktor Yang Mempengaruhi Produksi Getah Pinus}

\subsubsection{Faktor Internal}

Faktor internal yaitu faktor yang mempengaruhi hasil produksi getah pinus dari dalam pohon. Berdasarkan penelitian yang dilakukan di hutan pinus kabupaten poso, ada beberapa faktor internal yang mempengaruhi hasil produksi getah pinus, yaitu:

1) Jenis pohon pinus

Pada umumnya di Indonesia hanya tumbuh satu jenis pohon pinus yaitu merkusi atau tusam (Pinus Merkusi Jungh. Et de Vries) termasuk juga di Kabupaten Poso. Pinus merkusi atau tusam menghasilkan $6 \mathrm{~kg}$ getah di setiap pohon dalam kurun waktu satu tahun, terletak di bagian kayu gubal sebesar $36 \%$.

2) Persen kayu gubal

Kayu gubal merupakan bagian kayu yang masih muda terletak di tepi atau pinggiran kayu mengelilingi kayu teras atau inti kayu. Kayu gubal merupakan faktor penting dalam produksi getah pinus karena pinus dengan kayu gubal yang baik dapat menghasilkan getah maksimum sebab kayu gubal adalah tempat akumulasi getah tertinggi (36\%). Besarnya kayu gubal ditentukan juga oleh kesehatan pohon dan umur pohon oleh sebab itu petani getah pinus di Kabupaten Poso berusaha agar pohon pinus tetap sehat dan lestari dengan cara merawatnya dengan baik.

3) Kesehatan Pohon

Kesehatan pohon pinus sangat mempengaruhi produksi getah karena jika pohon pinus sehat maka persen kayu gubalnya akan baik sehingga produksi getah pinus akan maksimal. Petani pinus di kabupaten poso, menjaga kesehatan pohon dengan cara rutin membersihkan pohon dan sekitarnya.

4) Perakaran

Sistem perakaran yang luas pada pohon pinus berarti mampu membuat pohon pinus menyerap lebih banyak zat makanan dari tanah, sehingga getah lebih banyak. Hutan pinus di kabupaten poso di tanam oleh masyarakat dan TNI dalam upaya reboisasi lahan, dalam sistem perakarannya sekitar 1-2 meter.

5) Persen tajuk

Pohon pinus dengan tajuk lebih banyak memungkinkan proses fotosintesis lebih optimal dan menghasilkan banyak getah. Hutan pinus di kabupaten poso memiliki tinggi pohon rata-rata $20-25$ meter, membuat petani sangat jarang untuk menebang tajuk pada pohon sehingga persen tajuk yang ada masih sangat alami. Persen tajuk juga tergantung pada kesehatan pohon, jika poho sehat maka persen tajuk juga akan meningkat.

\subsection{Faktor Eksterna}

Faktor eksternal yaitu faktor yang disebabkan oleh lingkungan luar pohon. Dari hasil penelitian ada beberapa faktor internal yang mempengaruhi produksi getah pinus yaitu :

1) Iklim dan Tempat tumbuh

Pohon pinus yang tumbuh di daerah dengan curah hujan tinggi atau di daerah dingin dengan tinggi lebih dari $700 \mathrm{~m}$ dpl menghasilkan getah sedikit. Curah hujan rata-rata kurang dari $2000 / \mathrm{mm} / \mathrm{thn}$, suhu antara $22-28^{\circ} \mathrm{C}$ dan tinggi tempat $400-700 \mathrm{~m}$ dari permukaan laut menghasilkan getah optimal.

Wilayah Poso berada pada ketinggian $600 \mathrm{~m}$ dpl dan termasuk daerah hujan tropis (Af). Suhu rata-rata tahunan mencapai $25,8^{\circ} \mathrm{C}$, bulan terpanas adalah bulan Oktober dengan suhu bulanan rata-rata mencapai $26,4^{\circ} \mathrm{C}$ dan bulan yang paling dingin adalah bulan Juli dengan suhu rata-rata $25,3^{\circ} \mathrm{C}$. Curah hujan tahunan rata-rata adalah $1694,2 \mathrm{~mm}$, dan curah hujan maksimum bulan Juli mencapai 182,9 $\mathrm{mm}$ curah hujan minimum bulan januari mencapai $111,8 \mathrm{~mm}$. Oleh 
karena itu iklim dan tempat tumbuh hutan pinus di kabupaten Poso dapat menghasilakan getah yang optimal adanya perbedaan pada hasil produksi getah setiap kelompok tergantung pada faktor perlakuan manusia.

\section{2) Umur pohon}

Umur pohon sangat berpengaruh pada produksi getah pinus, semakin tua pohon maka getahnya akan semakin banyak dan bagus. Getah pohon pinus mulai bisa dipanen mulai pada saat umur pohon pinus mencapai 10 tahun. Hutan pinus di kabupaten Poso di tanam pada tahun 1982 untuk reboisasi lahan kritis dan mulai di olah pada umur 23 tahun pada tahun 2005 . Dengan begitu pada tahun sekarang hasil produksi getah pinus akan sangat optimal.

3) Luas tempat tumbuh

Luas tempat tumbuh atau luas lahan memiliki pengaruh yang sangat penting pada penelitian ini sebab semakin besar luas lahanya maka akan semakin besar juga hasil produksi getahnya.

\subsection{Faktor Perlakuan Manusia}

\section{1) Bentuk sadapan}

Bentuk sadapan dengan metode koakan hasilnya akan lebih banyak di bandingkan dengan metode Rill dan Bor. Di Kabupaten poso petani hanya menggunakan satu metode yaitu koakan yang di sebut dengan mowingku jika di Kabupaten Poso dengan menguanakan alat sadap bernama wingku.

\section{2) Arah sadapan}

Luka sadapan yang mengahadap timur paling banyak menghasilakan getah, kemudian disusul arah utara, selatan dan barat, ini dikarenakan arah timur terlebih dahulu terkena sinar matahari. Petani getah pinus di Kabupaten Poso sudah menerapakan ini sejak awal pemanenan getah.

\section{3) Arah pembaharuan}

Arah pembaruan sadapan akan lebih banyak menghasilkan getah jika ke arah atas di bandingkan ke arah bawah. Dari hasil wawancara kepada petani getah pinus di Kabupaten Poso masih jarang petani yang memperhatiakan arah pembaruan sadapan ini, akibatnya hasil produksi getah masih tidak menentu di setiap panen.

\section{4) Upaya stimulan}

Upaya stimulan dilakukan dengan cara merangsang pada luka sadapan dengan bahan kimia. Dalam hasil wawancara dengan beberapa petani getah pinus di Kabupaten Poso belum ada yang menggunakan upaya stimulan ini dikarenakan masih kurangnya bahan untuk stimulan serta minimnya pengetahuan bagaimana cara melakukan upaya stimulan yang baik dan juga pemerintah Kabupaten Poso belum memberikan izin untuk melakukan upaya ini.

5) Jumlah tenaga kerja penyadap

Pemanenan getah dilakukan kelompok tani hutan oleh karena itu jumlah tenaga kerja sangat berpengaruh penting pada hasil produksi getah pinus.

6) Waktu kerja tenaga kerja

Waktu kerja tenaga kerja juga sangat mempengaruhi produksi getah pinus semakin besar jumlah jam kerja petani semakin besar juga hasil produksinya. Dalam penelitian ini waktu kerja tenaga kerja di dapat dari jumlah rata-rata jam kerja setiap kelompok di kalikan dengan jumlah tenaga kerja jadi semakain banyak tenaga kerja semakin banyak juga jumlah jam kerja kelompok.

\subsection{Analisis Data}

\subsubsection{Uji Asumsi Klasik}

Sebelum dilakukan pengujian regresi linier berganda, terlebih dahulu dilakukan pengujian asumsi klasik untuk memberikan kepastian bahwa persamaan regresi yang didapatkan memiliki ketepatan dalam estimasi, tidak bias dan konsisten. Uji asumsi klasik yang digunakan dalam penelitian ini adalah uji multikolinearitas, uji heterokedastisitas dan uji normalitas.

1) Uji Multikolinearitas

Hasil uji multikolinearitas menggunakan salah satu software statistika ditunjukan pada tabel 3 berikut:

Tabel 2. Uji Multikolinearitas (1)

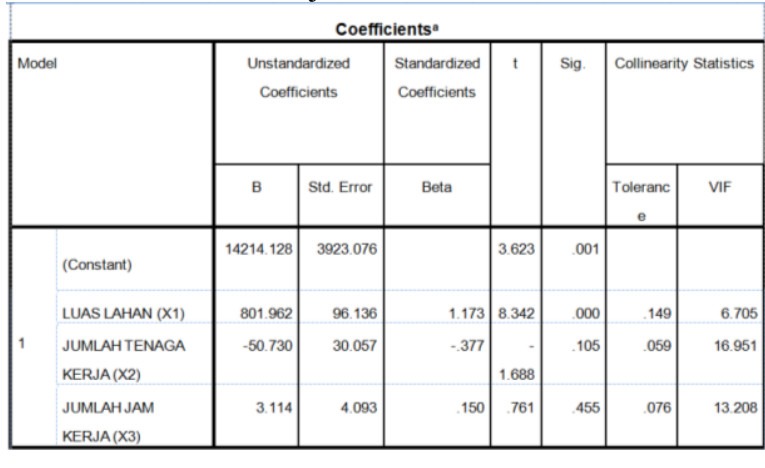

Pada tabel 2 terlihat bahwa terjadi multikolinearitas atau hubungan yang kuat antara variabel jumlah tenaga kerja $\left(X_{2}\right)$ dan variabel jumlah jam kerja $\left(X_{3}\right)$ ditunjukan dengan nilai tolerance kedua variabel tersebut lebih kecil dari 0,1 (tolerance $<0,1$ ) dan nilai VIFnya lebih besar dari 10 (VIF > 10). Model regresi yang baik yaitu tidak terjadi korelasi diantara variabel independen atau nilai tolerance harus lebih besar dari 0,1 (tolerance $\geq 0,1$ ) dan nilai VIF lebih kecil atau sama dengan 10 (VIF $\leq 10)$. Oleh karena itu untuk mengatasinya maka dikeluarkan salah satu variabel yang mengalami gejala multikolinearitas yaitu $\left(X_{3}\right)$. Dengan demikian dilakukan pengujian kembali variabel dependent $(Y)$ dengan dua variabel independen $\left(X_{1}, X_{2}\right)$, dan hasilnya dapat dilihat pada tabel 3 berikut:

Tabel 3. Uji Multikolinearitas (2)

\begin{tabular}{|c|c|c|c|c|c|c|c|c|}
\hline \multicolumn{9}{|c|}{ Coefficients $^{a}$} \\
\hline \multirow{2}{*}{\multicolumn{2}{|c|}{ Model }} & \multicolumn{2}{|c|}{$\begin{array}{l}\text { Unstandardized } \\
\text { Coefficients }\end{array}$} & \multirow{2}{*}{ 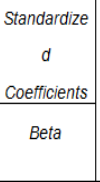 } & \multirow[t]{2}{*}{$t$} & \multirow[t]{2}{*}{ Sig. } & \multicolumn{2}{|c|}{$\begin{array}{l}\text { Collinearity } \\
\text { Statistics }\end{array}$} \\
\hline & & B & Std. Error & & & & $\begin{array}{c}\text { Toleran } \\
c e\end{array}$ & VIF \\
\hline \multirow{3}{*}{1} & (Constant) & 14043.743 & 3882.146 & & 3.618 & .001 & & \\
\hline & LUAS LAHAN (X1) & 810.454 & 94.644 & 1.185 & 8.563 & .000 & .151 & 6.614 \\
\hline & $\begin{array}{l}\text { JUMLAH TENAGA } \\
\text { KERJA (X2) }\end{array}$ & -32.876 & 18.610 & -245 & -1.767 & .090 & .151 & 6.614 \\
\hline
\end{tabular}

Dari tabel 3 terlihat bahwa nilai tolerance kedua variabel independen lebih besar atau sama dengan 0,1 (tolerance $\geq 0,1$ ) dan nilai VIFnya lebih kecil atau sama dengan 10 (VIF $\leq 10$ ) yang berarti sudah tidak terjadi gejala multikolinearitas. Dengan demikian dapat disimpulkan bahwa model regresi telah memenuhi asumsi multikolinearitas.

2) Uji Heterokedastisitas

Hasil pengujian heterokedastisitas dapat dilihat pada plot yang ditunjukan oleh gambar 1 berikut: 


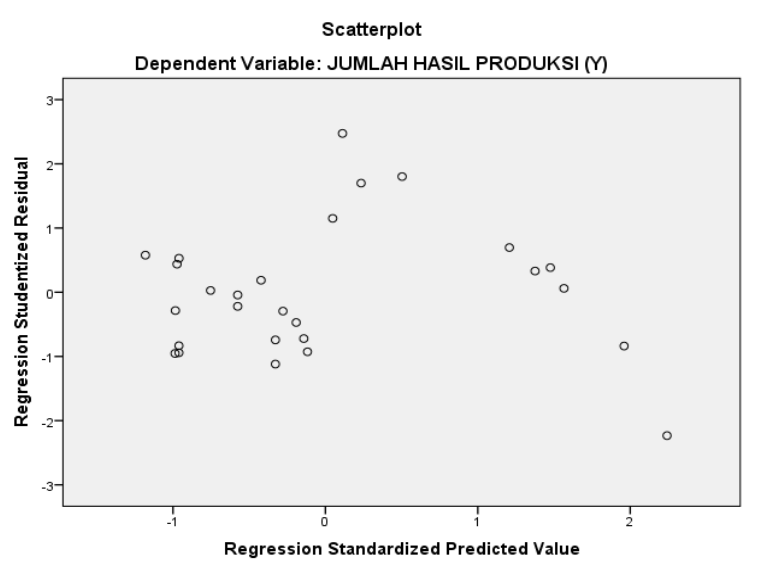

Gambar 1. Scatterplot Uji Heterokedastisitas

Berdasarkan gambar 1 dapat dilihat bahwa tidak terjadi gejala heterokedastisitas, karena titik-titik data tersebar di atas dan di bawah atau disekitar angka o dan tidak membentuk pola tertentu. Dengan demikian dapat disimpulkan bahwa model regresi telah memenuhi asumsi heterokedastisitas.

\section{3) Uji Normalitas}

Model regresi yang baik yaitu data berdistribusi normal. Untuk mengetahui data berdistribusi normal atau tidak dapat dilihat dari sebaran data (titik) pada sumbuh diagonal dari grafik histogram dan p-plot. Ketentuan data berdistribusi normal adalah jika data menyebar disekitar garis diagonal dan mengikuti arah garis diagonal atau grafik histogramnya.

Hasil uji normalitas dapat dilihat pada plot yang ditunjukan oleh gambar 2 berikut:

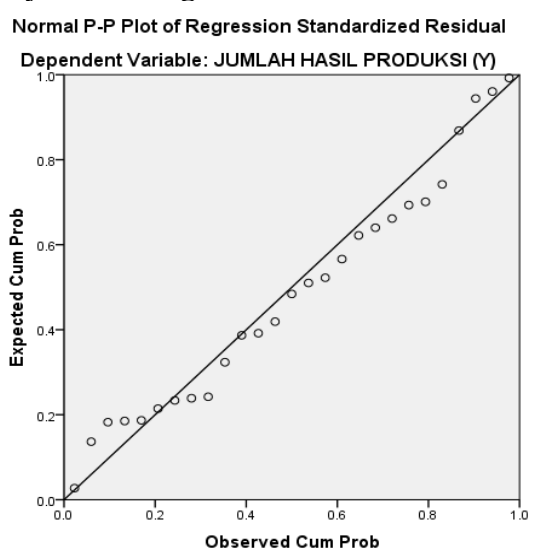

Gambar 2. Grafik Histogram dan P-Plot Uji Normalitas

Berdasarkan gambar 2 dapat dilihat bahwa data berdistribusi normal, karena titik-titik data tersebar menyebar disekitar garis diagonal dan mengikuti arah garis diagonal atau grafik histogramnya. Dengan demikian dapat disimpulkan bahwa model regresi telah memenuhi asumsi normalitas.

\subsubsection{Analisis Regresi Linier Berganda}

Hasil analisis regresi berganda variabel luas lahan $\left(X_{1}\right)$ dan jumlah tenaga kerja $\left(X_{2}\right)$ terhadap hasil produksi getah pinus (Y) di Kabupaten Poso diperoleh persamaan sebagai berikut:

$$
Y=14043,743+810,454 X_{1}-32,876 X_{2}
$$

1) Uji F (Simultan) berikut:

Hasil analisis uji $\mathrm{F}$ dapat dilihat pada tabel 4

Tabel 4. Uji F ANOVA $^{2}$

\begin{tabular}{|c|c|c|c|c|c|c|}
\hline \multicolumn{2}{|c|}{ Model } & Sum of Squares & df & Mean Square & $\mathrm{F}$ & Sig. \\
\hline \multirow{3}{*}{1} & Regression & 27169246721.443 & 2 & $\begin{array}{r}13584623360.7 \\
22\end{array}$ & 160.640 & $.000^{\circ}$ \\
\hline & Residual & 2029573613.075 & 24 & 84565567.211 & & \\
\hline & Total & 29198820334.519 & 26 & & & \\
\hline
\end{tabular}

Berdasarkan hasil analisis uji $\mathrm{F}$ pada tabel 4, diperoleh nilai $F_{\text {hitung }}$ yaitu 160,640 lebih besar dari nilai $F_{\text {tabel }}$ yang diperoleh dari persamaan (3) yaitu 3,39 $\left(F_{\text {hitung }}>F_{\text {tabel }}\right)$, atau nilai signifikansi lebih kecil dari taraf signifikansi yang digunakan dalam penelitian ini yaitu 0,05. Hal ini menunjukkan bahwa variabel independen secara bersama-sama berpengaruh signifikan terhadap variabel dependen. Dengan demikian dapat disimpulkan hipotesis $H_{1}$ diterima hal ini menunjukan bahwa luas lahan $\left(X_{1}\right)$ dan jumlah tenaga kerja $\left(X_{2}\right)$ secara bersama-sama berpengaruh terhadap hasil produksi getah pinus di Kabupaten Poso.

2) Uji t (Parsial) berikut:

Hasil analisis uji $\mathrm{t}$ dapat dilihat pada tabel 5

Tabel 5. Uji t

\begin{tabular}{|c|c|c|c|c|c|c|}
\hline \multirow[t]{2}{*}{ Mode } & & \multicolumn{2}{|c|}{ Unstandardized Coefficients } & \multirow{2}{*}{$\begin{array}{c}\text { Standardized } \\
\text { Coefficients } \\
\text { Beta }\end{array}$} & \multirow[t]{2}{*}{$t$} & \multirow[t]{2}{*}{ Sig. } \\
\hline & & B & Std. Error & & & \\
\hline \multirow{3}{*}{1} & (Constant) & 14043.743 & 3882.146 & & 3.618 & .001 \\
\hline & LUAS LAHAN (X1) & 810.454 & 94.644 & 1.185 & 8.563 & .000 \\
\hline & $\begin{array}{l}\text { JUMLAH TENAGA KERJA } \\
(\mathrm{X} 2)\end{array}$ & -32.876 & 18.610 & -.245 & -1.767 & .090 \\
\hline
\end{tabular}

a. Dependent Variable: JUMLAH HASIL PRODUKSI (Y)

Berdasarkan hasil analisis uji $\mathrm{t}$ pada tabel 5 , diperoleh nilai signifikansi untuk variabel luas lahan $\left(X_{1}\right)$ lebih kecil dari taraf signifikansi yang digunakan dalam penelitian ini yaitu 0,05 atau nilai $t_{\text {hitung }}$ lebih besar dari nilai $t_{\text {tabel }}$ yang diperoleh dari persamaan (4) yaitu $t_{\text {hitung }} 8,563>t_{\text {tabel }} 2,063$ yang berarti bahwa luas lahan memiliki pengaruh secara signifikan terhadap hasil produksi getah pinus di Kabupaten Poso.

Untuk variabel jumlah tenaga kerja $\left(X_{2}\right)$ diperoleh nilai signifikansi o,o9 lebih besar dari taraf signifikansi yang digunakan dalam penelitian ini yaitu 0,05 (0,09 > $0,05)$ atau nilai $t_{\text {hitung }}$ lebih kecil dari nilai $t_{\text {tabel }}$ yang diperoleh dari persamaan (4) yaitu $t_{\text {hitung }}-1,767<$ $t_{\text {tabel }}$ 2,063 yang berarti bahwa jumlah tenaga kerja tidak memiliki pengaruh secara signifikan terhadap hasil produksi getah pinus di Kabupaten Poso.

3) Koefisien Determinasi $\left(R^{2}\right)$

Hasil analisis koefisien determinasi $\left(R^{2}\right)$ dapat dilihat pada tabel 6 berikut: 
Tabel 6. Koefisien Determinasi

\begin{tabular}{|l|r|r|r|c|}
\hline \multicolumn{5}{|c|}{ Model Summary } \\
\hline Model & \multicolumn{1}{|c|}{$\mathrm{R}$} & \multicolumn{1}{|c|}{ R Square } & Adjusted R Square & $\begin{array}{c}\text { Std. Error of the } \\
\text { Estimate }\end{array}$ \\
\hline 1 & $.965^{2}$ & .930 & .925 & 9195.954 \\
\hline
\end{tabular}

Berdasarkan hasil analisis, koefisien determinasi $\left(R^{2}\right)$ pada tabel 6, diperoleh nilai sebesar 0,930 yang berarti variansi hasil produksi getah pinus $(Y)$ dapat dijelaskan oleh luas lahan $\left(X_{1}\right)$ dan jumlah tenaga kerja $\left(X_{2}\right)$ sebesar $93 \%$ sedangkan sisanya dijelaskan oleh variabel lain yang tidak diteliti.

\section{PENUTUP}

\subsection{Kesimpulan}

Hasil analisis menunjukkan bahwa variabel luas lahan $\left(X_{1}\right)$ dan jumlah tenaga kerja $\left(X_{2}\right)$ mempengaruhi jumlah hasil produksi getah pinus $(Y)$ yang ada di Kabupaten Poso dengan model regresi linier berganda :

$$
Y=14043,743+810,454 X_{1}-32,876 X_{2}
$$

\subsection{Saran}

Pemerintah terutama Dinas Kehutanan Kesatuan Pengelolaan Hutan (KPH) Sintuwu Maroso Kabupaten Poso Sulawesi Tengah diharapkan dapat memberikan penyuluhan cara penyadapan getah yang baik, dan meninjau kembali sistem perizinan pengelolaan getah pinus dengan menyesuaikan antara luas lahan dan jumlah anggota dalam satu kelompok tani hutan, sehingga terjadi keseimbangan antara luas lahan penyadapan dengan jumlah penyadap.

\section{REFERENSI}

[1] Sukadaryati. (2014). Pemanenan getah pinus menggunakan tiga cara pennyandapan. Jurnal Penelitian Hasil Hutan 32 (1):62-70

[2] Panshin \& De Zeueuw. (1980). Textbook of wood technology. New York, Toronto: McGraw Hill Book.Company.

[3] Van steenis, C.G.G.J. 2003. Flora. P. T. Pradaya Paramita. Jakarta.

[4] Dahlian, E. Dan Hartoyo. 1997. Komponen Kimia Terpentin dari Getah Tusam (Pinus Merkussi) Asal Kalimantan Barat. Info Hasil Hutan. Badan Pengembangan dan Penelitian Kehutanan. Bogor.

[5] [FAHUTAN IPB] Fakultas kehutanan Institut Pertanian Bogor. 1989. Penyempurnaan Cara Penyadapan Getah Pinus Untuk Peningkatan Produksi Getah. Laporan Penelitian Fakultas Kehutanan IPB dan Perum Perhutani.

[6] Hiariey dan Karuwal. 2009. Bagaimana Memanfaatkan Excel untuk Menghitung Regresi dan Korelasi linier. Jurnal Ilmiah Agribisnis dan Perikanan. Vol. 2(2):30-33

[7] Hasan, M. Iqbal. 2008. Pokok-Pokok Materi
Statistik 1 (statistik deskriptif). Jakarta : Bumi Aksara.

[8] R.Lawendatu, Jamner. 2014. Regresi Linier Berganda Untuk Menganalisis Pendapatan Petani Pala. Jurnal Ilmiah FMIPA UNSRAT. Vol. 3:67

[9] Ghozali, Imam. 2012. Aplikai Analisis Multivariate dengan Program IBM SPSS 20. Semarang : Badan Penerbit - Universitas Diponegoro.

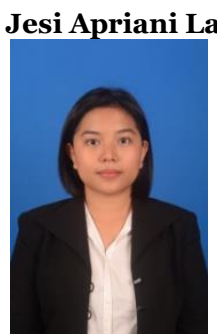

ka (jesilateka01@gmail.com)

Lahir di Poso, Sulawesi Tengah pada tanggal 01 April 1997. Menempuh pendidikan tinggi Jurusan Matematika, FMIPA, Universitas Sam Ratulangi Manado. Tahun 2019 adalah tahun terakhir ia menempuh studi. Makalah ini merupakan hasil penelitian skripsinya yang dipublikasikan.

Tohap Manurung(Tohapm@unsrat.ac.id)

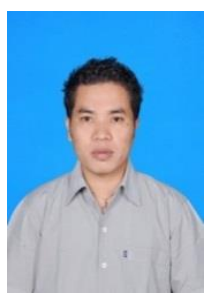
Lahir pada tanggal 24 Desember 1979.Pada tahun 2003 mendapatkan gelar Sarjana Sains (S.Si) yang diperoleh dari Universitas Sumatera Utara.Gelar Magister Sains diperoleh dari Institut Teknologi Bandung pada tahun 2010.Ia bekerja di UNSRAT di Program Studi Matematika sebagai pengajar akademik tetap UNSRAT

Jantje D. P rang (jantjedprang@yahoo.com)

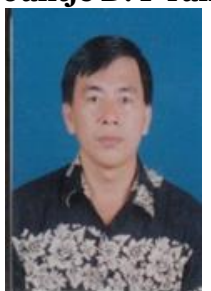
pada tanggal 20 Desember 1958. Pada tahun 1983 mendapatkan gelar Sarjana S1 (Drs) yang diperoleh dari IKIP Negeri Manado. Gelar Magister Sains (M.Si) diperoleh dari Institut Pertanian Bogor pada tahun 2006. Ia bekerja di UNSRAT di Program Studi Matematika sebagai pengajar akademik tetap UNSRAT. 